\title{
"I learned that I am loved": Older adults and undergraduate students mutually benefit from an interprofessional service-learning health promotion program
}

\author{
Britteny M. Howell , Leslie C. Redmond \& Samantha Wanner
}

To cite this article: Britteny M. Howell , Leslie C. Redmond \& Samantha Wanner (2020): "I learned that I am loved": Older adults and undergraduate students mutually benefit from an interprofessional service-learning health promotion program, Gerontology \& Geriatrics Education, DOI: $10.1080 / 02701960.2020 .1791104$

To link to this article: https://doi.org/10.1080/02701960.2020.1791104

曲 Published online: 13 Jul 2020.

Submit your article to this journal $₫$

View related articles

View Crossmark data $\asymp$ 


\title{
"I learned that I am loved": Older adults and undergraduate students mutually benefit from an interprofessional service- learning health promotion program
}

\author{
Britteny M. Howell (D) ${ }^{\mathrm{a}, \mathrm{b}}$, Leslie C. Redmond (D) ${ }^{c}$, and Samantha Wanner ${ }^{\mathrm{a}, \mathrm{d}}$ \\ aDivision of Population Health Sciences, University of Alaska Anchorage, Anchorage, Alaska, USA; ${ }^{\text {DNational }}$ \\ Resource Center for Alaska Native Elders, University of Alaska Anchorage, Anchorage, Alaska, USA; 'Department \\ of Dietetics \& Nutrition, University of Alaska Anchorage, Anchorage, Alaska, USA; 'Department of Health, \\ Physical Education, and Recreation, University of Alaska Anchorage, Anchorage, Alaska, USA
}

\begin{abstract}
Although benefits of service-learning and interprofessional education (IPE) have been well documented to be effective for students in gerontology, few curricula appear to integrate both aspects into a single experience for undergraduate students in public health. We discuss the development and implementation of an IPE servicelearning health promotion program embedded within two different departments at a mid-sized university. Students worked in interdisciplinary teams and acquired IPE learning outcomes while they engaged in their first experiences working with diverse older adults at a lowincome independent-living housing community. Twenty-five students each team-taught two sessions on nutrition, physical activity, and stress reduction techniques in a 10-week program. Qualitative and quantitative results showed significant learning outcomes from the students about the needs of the aging population and increased comfort working with seniors. Older participants in the program also reported positive health and psychological outcomes from participation. Challenges, next steps, and recommendations are also discussed.
\end{abstract}

\section{KEYWORDS}

Population health;

undergraduate education; health promotion; nutrition; physical activity

Students entering the health professions will be faced with an unprecedented number of older adults in the healthcare system during their career. In 2018, more than 52 million adults over the age of 65 were reported in the United States, accounting for $16 \%$ of the total population. These numbers are expected to continue to rise over the next three decades (U.S. Census Bureau, 2018). However, undergraduate students in the health professions rarely consider working with older adults when making their career choices (Haron, Levy, Albagli, Rotstein, \& Riba, 2013; Meiboom, De Vries, Hertogh, \& Scheele, 2015; Ní Chróinín et al., 2013). Since students do not intend to work with older adults, they rarely seek out educational opportunities to learn about this population. This means that many future health practitioners may be ill-prepared for the realities of working with an older population when they graduate.

Service-learning can provide hands-on experiential learning for students with a diverse population while also providing an important service back to that community (Cohen, Hatchett, \& Eastridge, 2006). Likewise, interprofessional education (IPE) helps to prepare 
a collaborative health workforce that can respond to the complexity of needs in a diverse older adult population (Interprofessional Education Collaborative, 2016). Service-learning and IPE are both considered high-impact teaching practices that can have a positive effect on student attitudes, learning outcomes, and career readiness (De Los Santos, McFarlin, \& Martin, 2014).

However, there remains little guidance on how to best integrate service-learning and IPE principles into a single gerontology curriculum for undergraduate students in the health professions. This article discusses the development, implementation, and results of a service-learning, interprofessional health promotion project that was piloted in two different departments at a mid-sized, teaching-focused university in the Pacific Northwest. This project is being used as the foundation for the development of a new IPE course in the College of Health aimed at increasing students' exposure to, and interest in, working with older adults in their respective health fields.

\section{Service-learning}

Service-learning is a course-based, credit-bearing educational experience where students participate in an organized service activity and reflect on the service activity to gain further understanding of course content and an enhanced sense of civic responsibility (Bringle \& Hatcher, 1995). By bringing together teaching, research, and service, this method often gives students deeper engagement with, and understanding of, the course curriculum than traditional didactic-style learning while also providing a service back to their community (Steinke \& Fitch, 2014). Service-learning is important in the health professions because students learn through civic engagement and develop an enhanced sense of personal values while working directly with their future patient population (Bringle, Games, Foos, Osgood, \& Osborne, 2000). Through service-learning, students apply theoretical concepts from course material to real-life situations with older adults while increasing collaboration between the academic community and the network of professionals in the field of aging (Cohen et al., 2006).

Service-learning has become increasingly popular in gerontology and geriatric education (Brown \& Bright, 2017; Vandsberger \& Wakefield, 2006; Zucchero, 2010). Service-learning not only provides a practice-oriented approach to gerontology and geriatric course content, but can also expose undergraduate students to a population with which they often have little first-hand experience. Research shows that students who have little contact with older adults tend to have lower opinions and intentions regarding working with an aging population in their future careers (Gorelik, Damron-Rodriguez, Funderburk, \& Solomon, 2000; Meiboom, de Vries, Hertogh, \& Scheele, 2015). Increasing contact between undergraduate students and older adults provides a way to increase student interest in the geriatric population. Students engaged in such gerontological service-learning opportunities report improved positive attitudes about older adults and aging, and increases in their desire to work with a geriatric population (Gutheil, Chernesky, \& Sherratt, 2006; Tam, 2014; Vandsberger \& Wakefield, 2006).

\section{Interprofessional education}

In addition to service-learning, interprofessional education (IPE) has garnered attention recently within gerontology and geriatric education (Goldberg, Koontz, Rogers, \& Brickell, 
2012; Schapmire et al., 2018). IPE is defined as two or more professions come together to engage in learning from, with, and about each other to improve communication, collaboration, and the quality of care (WHO, 2010). IPE curricula generally include team-teaching models with professionals from different disciplines and focus on student learning outcomes such as how to respectfully work with other professionals; effective communication with other patients, families, communities, and health professionals; and appropriately assess the healthcare needs of patients and populations in light of one's own scope of practice and those of other professions. Six national schools of health professions constitute the Interprofessional Education Collaborative (IPEC) working group that defines IPE core competencies and publishes best practices.

IPE has been shown to be an effective way to increase student experience and knowledge regarding their roles, scope of practice, and positive attitudes toward teamwork (Curran, Mugford, Law, \& MacDonald, 2005). IPE has been utilized in gerontology and geriatric education to improve team-based collaboration and communication between healthcare practitioners, physical therapists, occupational therapists, and social workers to manage the complex needs of older patients (Gould, Lee, Berkowitz, \& Bronstein, 2015; Richardson, Cooper, Swanson, \& Ward, 1996). Although interest in IPE has been increasing in gerontology and geriatric education in recent years, many health students are still rarely exposed to such collaborative team-based practice in the management of complex conditions for older adults before they graduate (Goldberg et al., 2012). Likewise, there is little guidance in the gerontology education literature on how best to incorporate servicelearning and IPE principles into a single undergraduate curriculum in public health.

Instead, much of the IPE service-learning research is focused on nursing and medical education for students who will provide direct patient care in medical clinics (for example, see Dacey, Murphy, Anderson, \& McCloskey, 2010; Gellis et al., 2019; Lally et al., 2019; Lee, Hayes, McConnell, \& Henry, 2013; Matthews, Parker, \& Drake, 2012; Wen et al., 2019). This literature is of limited utility for non-direct service providers because medical students have very different skillsets and educational needs than undergraduates in the population health sciences (e.g. public health) who are involved in the management of care, promoting health behavior change, and influencing health policy rather than providing direct patient care (Morano \& Damiani, 2019). However, interprofessional care teams greatly benefit from the inclusion of public health and social work students and perspectives (Morano \& Damiani, 2019). Since the IPEC core competencies now focus on community, population, and public health, rather than just focusing on individual patient outcomes (Interprofessional Education Collaborative, 2016), there remains a need to identify best practices in service-learning IPE gerontology course curricula for undergraduates in public health.

\section{The service-learning IPE program}

This article describes the development and implementation of a service-learning IPE health promotion program called Community Wellness Breaks (CWB) for older adults. We also report how this project was incorporated into the course curriculum to meet gerontology course competencies as well as the project's evaluation results, limitations, next steps, and further recommendations. Research permissions and oversight were obtained from the University of Alaska Institutional Review Board (IRB). All of the students engaged in this 
project were considered research assistants and had received human subjects research CITI certification and IRB approval to participate in the project (IRB \#1443234). Written informed consent was obtained from all older resident participants at the beginning of each session.

The 10-week CWB program was built to bridge the aforementioned objectives, combining service-learning and principles of IPE to deliver a student-led, community-based health promotion program to older adults in a diverse, low-income, urban housing community. This program was designed to provide practical experience and intergenerational learning in the community among undergraduate students who do not typically receive such opportunities within their academic programs in population health sciences, kinesiology, and dietetics and nutrition. The program development consisted of a needs assessment, data analysis, program planning, facilitator training and orientation, program implementation, and evaluation phases (see Figure 1, above).

\section{Program development}

Faculty in the departments of population health sciences, kinesiology, and dietetics and nutrition collaborated with a local public housing authority to develop a health promotion program that would be delivered to low-income community-dwelling older adults in their housing complex. A needs assessment was developed in which a graduate student in public health served as project manager for five undergraduate students in population health sciences who conducted five focus groups with 25 older adult residents (aged 50+ years) during summer 2019. These focus groups aimed to find out the residents' educational needs and desires regarding healthy aging and general wellness for the proposed student-led program. Project faculty assisted students in creating a semi-structured interview guideline of questions and prompts (see Appendix A). These open-ended questions asked residents to express what information they would like to see in a new health program in their community. Each focus group was held at the housing community and lasted between 47 and 84 minutes. All older resident participants were compensated with \$10 USD gift cards for their time and participation (Mduluza, Midzi, Duruza, \& Ndebele, 2013).

The five undergraduate research assistants collated all the focus group session notes and summarized them into general themes related to nutrition education, physical activity needs, stress reduction techniques, and other general wellness information, under the direction of faculty. Student assistants also inquired as to the residents' preferred days and times of the week to hold the health promotion program classes at the housing community in the Fall semester. The focus group results indicated several areas where older adults desired more education, as summarized in Table 1, below.

Overall, the focus group results suggested that residents wanted an opportunity to learn new things, be social, and get physical activity in the convenience of their own housing community.

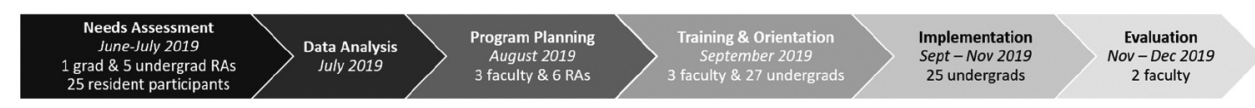

Figure 1. Timeline and work tasks in the development of the CWB program. 
Table 1. Summary of focus group results for the CWB program.

\begin{tabular}{|c|c|}
\hline Topic & Suggestion \\
\hline Nutrition & $\begin{array}{l}\text { - Making health food choices at social events } \\
\text { - Cutting down on convenience foods } \\
\text { - Easy-to-consume options } \\
\text { - Portion size education } \\
\text { - Healthy convenience food options }\end{array}$ \\
\hline Exercise & $\begin{array}{l}\text { - How to modify exercises safely } \\
\text { - Sance classes near their location } \\
\text { - Safely improving balance } \\
\text { - Staying active despite mobility issues } \\
\text { - Low-cost exercise classes near the housing complex }\end{array}$ \\
\hline Healthy Aging & $\begin{array}{l}\text { - Normal aspects of aging, such as vision or memory loss } \\
\text { - How to identify abnormal health concerns } \\
\text { - Keeping involved in activities to prevent isolation } \\
\text { - What to expect as you continue aging }\end{array}$ \\
\hline Stress Reduction & $\begin{array}{l}\text { - Calming activities to do at home } \\
\text { - Communication tools to talk about mental health concerns with others } \\
\text { - Techniques that can be used in everyday life }\end{array}$ \\
\hline Community Engagement & $\begin{array}{l}\text { - How to find out about events going on in our community } \\
\text { - Organized arts and crafts time in our housing complex } \\
\text { - Game nights in our complex, such as Bingo }\end{array}$ \\
\hline Shopping on a Budget & $\begin{array}{l}\text { - Couponing } \\
\text { - How to shop and cook for one person } \\
\text { - Foods that are lower in sodium and sugar }\end{array}$ \\
\hline Attitude \& Motivation & $\begin{array}{l}\text { - Cutting out bad habits, such as soda drinking } \\
\text { - Keeping positive during the long, dark winter } \\
\text { - Creating new healthy habits } \\
\text { - Making connections and friends in the community }\end{array}$ \\
\hline
\end{tabular}

\section{Program implementation}

After the focus group data were summarized, the graduate student project manager and faculty members assisted the undergraduate students with creating the program logic model and the instructional components of the 10-week CWB program based on the focus group results. The research assistants identified the 10 most common themes to constitute each weekly topic. Then, working in teams, the students generated a first draft of the CWB curriculum by researching best practices and locating existing public health curricula for each weekly topic. Faculty members then quality-checked, edited, supplemented, and finalized the 10 curriculum modules so that they could be taught in 1-hour sessions by interprofessional teams of undergraduate students in population health sciences, kinesiology, and dietetics and nutrition (see Table 2, below).

This project was integrated as a course assignment into two courses at the university during Fall semester: the new 300-level health sciences course titled Public Health for an Aging Society and the existing 400-level kinesiology course Contemporary Personal Health Issues. In addition, one undergraduate student enrolled in a nutrition course participated in the project. For this pilot, students in these courses could choose to participate in facilitating this health promotion program for course credit or they could complete an alternate assignment. Twenty-five students participated, only two opted-out. Students who optedout reported they did so because they could not make the CWB program sessions fit into their existing school and work schedules.

This project addressed several course objectives, including (a) identify the main behavioral, social, and environmental factors that influence age-related outcomes of the 
Table 2. The 10-week CWB program curriculum.

\begin{tabular}{|c|c|c|}
\hline Schedule & Topic & Content \\
\hline Week 1 & What is Healthy Aging? & $\begin{array}{l}\text { - Overview of the aging process (biological and social aspects) } \\
\text { - Changes to expect in the cardiovascular system, body weight, and } \\
\text { metabolism } \\
\text { - What you can do about these changes }\end{array}$ \\
\hline Week 2 & $\begin{array}{l}\text { Physical Activity in Our } \\
\text { Community }\end{array}$ & $\begin{array}{l}\text { - Discussions to have with medical providers about adding exercise } \\
\text { - The "Alaska To Go" activity booklet from NIH Go4Life } \\
\text { - List of free \& low-cost exercise classes in Anchorage } \\
\text { - Ideas for free leisure-time activity (e.g. community gardening) }\end{array}$ \\
\hline Week 3 & $\begin{array}{l}\text { Changing Nutritional } \\
\text { Needs as We Age }\end{array}$ & $\begin{array}{l}\text { - Reduce calories, not nutrition } \\
\text { - Common deficiencies (fiber, fluids, protein, vit D \& B12, iron, calcium) } \\
\text { - Good sources of plant-based foods to fulfill these needs } \\
\text { - MyPlate for Older Adults } \\
\text { - "6 Ways to Eat Well As You Get Older" graphic from NCoA }\end{array}$ \\
\hline Week 4 & $\begin{array}{l}\text { Stress Reduction } \\
\text { Techniques }\end{array}$ & $\begin{array}{l}\text { - Introduction to mindfulness } \\
\text { - Discuss tai chi, yoga, etc. } \\
\text { - Brief guided meditation with breathing exercises } \\
\text { - Tips to integrate mindfulness into everyday activities (e.g. eating, walking, } \\
\text { etc.) }\end{array}$ \\
\hline Week 5 & Tips for Brain Health & $\begin{array}{l}\text { - Practice "thinking games" to improve memory (e.g. Sudoku, scrabble, } \\
\text { crosswords, puzzles, etc.) } \\
\text { - Engage in lifelong learning- learn or read something new! } \\
\text { - Seek out social interaction } \\
\text { - Keep stress under control \& get help when needed (provide list of local } \\
\text { mental health resources) } \\
\text { - Maintain healthy diet \& exercise }\end{array}$ \\
\hline Week 6 & Shopping on a Budget & $\begin{array}{l}\text { - Plan around sales, buy generic \& shop seasonal produce } \\
\text { - Do not shop on an empty stomach and stick to your list! } \\
\text { - Choose frozen or canned produce } \\
\text { - Choose meats and breads on sale, prepare some now and freeze the rest } \\
\text { - Gor later } \\
\text { - Go "meatless" at least one day a week (e.g. eggs, beans, seafood) } \\
\text { - Stock up on dried beans and lentils, consider buying in bulk }\end{array}$ \\
\hline Week 7 & $\begin{array}{l}\text { Importance of Social } \\
\text { Relationships }\end{array}$ & $\begin{array}{l}\text { - What does social support consist of? (e.g. emotional, intellectual, } \\
\text { instrumental) } \\
\text { - Impacts of social support on health for older adults } \\
\text { - Social interactions can slow mental declines } \\
\text { - Role of family and friends on social connectedness and health }\end{array}$ \\
\hline Week 8 & Positive Attitudes & $\begin{array}{l}\text { - Importance of attitude and optimism on healthy aging outcomes } \\
\text { - Mood boosters: exercise, nutrition, mental stimulation, healthy sexuality, } \\
\text { social connections and emotional support, preventive healthcare, quit } \\
\text { smoking } \\
\text { - Lead group through "Strengths Discussion Questions" and Strengths } \\
\text { - Exploration" activity (2018) Therapist Aid LLC (therapistaid.com) } \\
\text { - Provide "Gratitude Journal" worksheets }\end{array}$ \\
\hline Week 9 & Safe, Seated Exercises & $\begin{array}{l}\text { - List of reasons to stay active and obtain leisure-time activity } \\
\text { - Why should I care about strength training? } \\
\text { - Provide weekly activity logs } \\
\text { - Provide NIH Go4Life activity booklet and guide group through seated } \\
\text { exercises }\end{array}$ \\
\hline Week 10 & $\begin{array}{l}\text { Staying Engaged in Our } \\
\text { Community }\end{array}$ & $\begin{array}{l}\text { - Reasons to stay engaged in the community (cognitive, emotional, physical, } \\
\text { etc.) } \\
\text { - List of community volunteer opportunities for older adults in Anchorage } \\
\text { - List of "other things" and group discussion of staying engaged }\end{array}$ \\
\hline $\begin{array}{l}\text { End-of- } \\
\text { program } \\
\text { event }\end{array}$ & $\begin{array}{l}\text { Thank you for your } \\
\text { participation! }\end{array}$ & $\begin{array}{l}\text { - Healthy refreshments provided, drawings for prizes } \\
\text { - All students, staff, and faculty meet resident participants } \\
\text { - Surveys administered and a big "thank you" to everyone }\end{array}$ \\
\hline
\end{tabular}

individual older adult, (b) describe current strategies for health promotion and disease prevention for older adults, and (c) explain how an older population mutually influences and is impacted by social and health policy. By participating in the data collection, program design, implementation, and evaluation of this project, students were directly exposed to 
some of these individual and community influences on older adult health. Students who could not participate were able to meet course objectives by completing a research paper and presentation.

Early in Fall 2019, the faculty members taught a CWB program orientation and training session for all 25 undergraduate students in the two courses. This session covered logistics of teaching the program, the basics of the curriculum, how to respectfully speak with older adults and interact with diverse populations, and general professionalism. The session allowed the students to meet each other and form interprofessional teams before beginning the program. Students came together for IPE learning outcomes at several time points during the semester: the orientation training, during team preparatory meetings, and as they co-facilitated the program. Additionally, all three project faculty also guest lectured in both of the courses, ensuring students were obtaining important information on interprofessional communication and responsibilities of the different professions.

Each of the 25 students facilitated two sessions over the course of the 10-week program, resulting in 2-3 population health sciences students working with 2-3 kinesiology students to deliver each weekly session. Teams were created based on the students' schedules and availability. The order of weekly topics had been determined during the summer, so students were assigned to teach these topics based upon their availability. Each session consisted of at least 30 minutes of light physical activity and engaged older resident participants in conversation and discussion about the weekly topic. Students held random drawings for \$10 USD grocery store gift cards at the end of each weekly session in order to incentivize resident participation for this pilot program. The program concluded with a community event that featured surveys, prizes, refreshments, a "thank you" for housing staff, and IPE certificates of completion for the students.

\section{Program evaluation}

The program was evaluated with participant satisfaction surveys, a student IPE survey, and written student reflections. In total, 25 students participated in the CWB program, which served 14 older residents of the housing community, seven of whom completed evaluation surveys. The surveys were administered on the last day of the program, which had attendance of seven older resident participants. The satisfaction survey was created by program faculty, but the IPE survey was created by the university's Interprofessional Education Committee based on the IPEC core competencies (Interprofessional Education Collaborative, 2016). This tool is used to evaluate all university IPE courses and activities. This instrument was inputted into Qualtrics Survey Software and administered to students electronically.

\section{Resident participant results}

The seven older resident participants who completed the satisfaction survey at the end of the program reported high levels of satisfaction from the CWB program (see Appendix B, below). All survey respondents indicated they were satisfied or highly satisfied with the students' teaching performance and the quality of the program. Likewise, all older resident respondents agreed or strongly agreed that they have been able to apply what they have 
learned in their daily life; the program has the potential to improve health, quality-of-life outcomes, and social interactions; and that the program was a worthwhile investment.

However, two older resident participants indicated improvements could be made to the physical location of the program, a finding that was corroborated by student feedback on the program. Due to the number of student facilitators and resident participants, the program was held in the housing complex's largest room, an open space labeled the "community room." Since this room was located directly in front of the elevators, residents expressed a desire for a more secluded space that would not be disrupted by hallway traffic.

Older resident participants also provided qualitative responses to the survey. Respondents indicated the most valuable aspects of the program included having their voices heard, learning new exercises and nutritional tips, and perceived improvement in their balance. Two respondents indicated that the social and psychological benefits of the program were the most important. One woman indicated, "the interaction with my peers [was most valuable], because I learned that I am loved and wanted."

Older resident participants suggested a few improvements to the program. One female respondent indicated that some information about grocery shopping on a budget provided could have been more tailored to the resident's specific needs in this low-income community. Respondents also had ideas for future programs to be held in the housing community, including Alcoholics Anonymous meetings, board game night, and more social activities. One respondent suggested that the program had "too many different students" rotating through the weekly sessions, which made it hard for her to get to know individual facilitators and form relationships.

\section{Student outcomes}

Of the 25 participating students, 21 completed the online IPE survey (see Table 3, below). Although specific demographic information was not collected on individual students who participated in this project, the student body at this university is a mix of "traditional" (under age 25) and "non-traditional" (over age 25) college students. Most students participating in this project were between ages 22-35. This survey was administered to all students at the conclusion of the program via Qualtrics. Results were auto-generated in reports from the software. A majority of students (85.71\%) agreed or strongly agreed with questions 1-4 assessing the program's adherence to four of the IPEC competencies regarding diversity and patient-centered teamwork.

Approximately $90 \%$ of students who completed the IPE survey indicated that they agreed or strongly agreed with questions 5-12 regarding the impact that interprofessional education can have on understanding scope of practice, effective communication, and working within collaborative teams. Finally, students also agreed on question 13 that they found the program overall to be very helpful.

Although overall responses from students were positive, there were several suggestions for program improvement. Student recommendations included finding a larger and more private space to hold the sessions; however, the housing complex where the program took place had limited space available. Some students also reported feeling nervous to facilitate these sessions on their own, suggesting more practiced role-playing activities before teaching in the housing community. Students (and older resident participants) indicated that 
Table 3. Student IPE survey results.

\begin{tabular}{|c|c|c|c|}
\hline Question & Mean & $\begin{array}{l}\text { Std } \\
\text { dev. }\end{array}$ & Variance \\
\hline \multicolumn{4}{|l|}{ On a scale of 1 (strongly disagree) - 5 (strongly agree), I met/achieved the activity's learning objectives (below). } \\
\hline $\begin{array}{l}\text { 1. Embraced the cultural diversity and individual differences that characterize patients, } \\
\text { populations, and the health team. }\end{array}$ & 4.19 & 1.18 & 1.39 \\
\hline $\begin{array}{l}\text { 2. Engaged diverse professionals who complement one's own professional expertise, as well as } \\
\text { associated resources, to develop strategies to meet specific health and healthcare needs of } \\
\text { patients and populations. }\end{array}$ & 3.95 & 1.33 & 1.76 \\
\hline $\begin{array}{l}\text { 3. Communicated the importance of teamwork in patient-centered care and population health } \\
\text { programs. }\end{array}$ & 4.19 & 1.10 & 1.20 \\
\hline $\begin{array}{l}\text { 4. Engaged health and other professionals in shared patient-centered and population focused } \\
\text { problem-solving. }\end{array}$ & 4.10 & 1.31 & 1.71 \\
\hline \multicolumn{4}{|l|}{ On a scale of 1 (strongly disagree) - 5 (strongly agree), please indicate your attitude toward Interprofessional Education ... } \\
\hline 5. Interprofessional education will help respect and share the values of other health professions. & 4.29 & 1.16 & 1.35 \\
\hline $\begin{array}{l}\text { 6. Interprofessional education will help me understand my own and other professions roles and } \\
\text { limitations. }\end{array}$ & 4.29 & 1.20 & 1.44 \\
\hline $\begin{array}{l}\text { 7. Interprofessional education will help me communicate more effectively with patients/clients } \\
\text { and other professionals. }\end{array}$ & 4.38 & 1.17 & 1.38 \\
\hline 8. Interprofessional education will help perform effectively on teams and in different team roles. & 4.19 & 1.37 & 1.87 \\
\hline $\begin{array}{l}\text { 9. Collaboration with other professions will increase my awareness of the patient/client's health } \\
\text { status and or healthcare needs. }\end{array}$ & 4.38 & 1.17 & 1.38 \\
\hline 10. Collaboration with other professions will help me provide better patient/client care. & 4.29 & 1.20 & 1.44 \\
\hline $\begin{array}{l}\text { 11. Collaboration, relationship building, and teamwork skills are vital for students in all } \\
\text { healthcare programs/disciplines. }\end{array}$ & 4.29 & 1.16 & 1.35 \\
\hline 12. I welcome the opportunity to learn with and from other healthcare students/professionals. & 4.43 & 1.18 & 1.39 \\
\hline 13. On a scale of $\mathbf{1}$ (not helpful) - $\mathbf{5}$ (very helpful), overall I rate this activity as & 4.38 & 0.84 & 0.71 \\
\hline
\end{tabular}

there were times when more student facilitators attended a session than participants, which could be rectified with better planning, advertising, and more incentives for participation.

Several health sciences students $(\mathrm{N}=11)$ also wrote reflection papers about their CWB experiences for their coursework. These papers not only included similar suggestions and recommendations, but also elaborated on the benefits they experienced from program participation. One student indicated, "as a result of this class, I am more confident in by ability to help with older patients in medical school and in my future practice." Another student agreed, stating, "As a person who had little to no experience with working with older adults, I really enjoyed the interaction with this community and what we did for them in terms of physical activity and education." In fact, most students started their papers with statements about their limited experience and exposure to the senior population.

Although three students began this project with career interests that included the geriatric population (Occupational Therapy and Physical Therapy concentrations), most students wrote about how they had never considered a career in geriatrics before taking this course. While not all students reported major changes in their career paths, $54 \%$ of the reflection papers $(\mathrm{N}=6)$ indicated that students had opened themselves up to the possibility of focusing their work with seniors as a result of this community project. For example, one student wrote, "This class will definitely be a memorable experience that will forever have an impact on both my personal and professional life. I can honestly say my learnings from this class have definitely changed my views toward the aging population." Likewise, another student stated,

I knew I didn't want to work with children in my profession; however, I've had minimum experience with working with older adults. This project confirms my interest in wanting to use my skills and abilities to work with the aging population! 
Lastly, students reported more than just learning about aging and getting familiar with older adults as a patient population. Students also reported enjoying the nature of their work with older adults. One student reported,

I really love being a familiar face in the housing facility now, and the relationships that have been built there. I also adored how much the older adults love having the students around. I truly feel that the community learned from the Wellness Breaks and we, as students, got to have a helping hand in that.

Such student reflections indicate that this community-based service-learning health promotion program allowed them to learn how to design and deliver health education as well as formulate fun and rewarding relationships with older adults. Although the kinesiology students did not write formal reflection papers, they did have qualitative responses to the survey that also indicated rewarding experiences with a hard-to-reach population.

\section{Limitations}

There are several limitations to this small pilot project. First, the sample size of resident participants was low $(\mathrm{N}=14)$ and the survey response rate was even fewer $(\mathrm{N}=7)$, making it difficult to interpret and generalize their results. We do now know how those nonrespondent participants may differ from those who completed the survey, therefore these results are not considered statistically valid for broad generalizability. However, positive feedback from these respondents suggests that the program should continue in this community, and possibly expand to other housing complexes to help reduce some study limitations. For example, program expansion may increase the sample size and reliability of results.

Another limitation to this program is that it was divided between two different university courses. Students in kinesiology and population health sciences were given their regular weekly course instruction separately and only came together into interprofessional groups in order to prep for and to facilitate their weekly CWB sessions. Although students received guest lectures from all project faculty, students reported that they would have liked more regular interaction with the other students and faculty across disciplines in the classroom. Indeed, this is a major component of IPE best-practices that was not fully implemented in this pilot project, and provides room for future improvement.

Students were also expected to participate in CWB outside of their regularly scheduled class time, which made it difficult for two students to participate in the program, including any dietetics and nutrition students, who are enrolled in an entirely online program. However, this pilot project has informed the research team of necessary improvements to make and of the overall positive benefit to students and older adults of such a servicelearning IPE project.

\section{Next steps and recommendations}

The faculty are currently making several program improvements so that CWB will continue as a required component of a new 400-level interprofessional service-learning course titled: Physical Activity and Aging. This new course will integrate students across a variety of disciplines within the College of Health at the university so that classroom instruction and 
the service-learning project will be truly interprofessional. The new course will also utilize scheduled class time to deliver the CWB program in the housing community, so that all students are able to participate. Since the pilot produced positive results, we are expanding the program to other locations. The faculty have reached out to several other older adult housing communities so that there will not be so many students rotating through a single housing complex. By providing the CWB program in several locations, we can set up stable teams of students assigned to each community. We hope more seniors will be able to benefit and form relationships with a smaller number of student facilitators. We have also built a simulation component early into the new course, so that students have the ability to practice and get comfortable teaching this program.

Graduate students have updated the 10-week CWB curriculum to ensure the most up-todate, evidence-based, best-practices are being conveyed in each session. We also plan to strengthen the baseline and follow-up data collection measures for students and resident participants of the program to more accurately assess service-learning, IPE, and program outcomes. Pre- and post-tests will be administered to students to gauge knowledge of course objectives at the beginning and end of the semester. We will also administer knowledge, self-reported health, and body composition assessments of resident participants before and after program participation. Lastly, the project team plans to utilize a resident "champion" from the pilot program to help recruit and retain participants, as well as consult on the future program implementation and evaluation process (Evashwick \& Ory, 2005; Wallerstein \& Duran, 2006).

We have several recommendations for others wishing to embark upon the creation of a similar service-learning IPE project. We suggest that faculty invite undergraduate and/or graduate students to participate in as much of the program planning process as possible. Having the students facilitate focus groups before the project commenced helped them to feel comfortable with this population and get familiar with the location before the program began. We strongly recommend some needs assessment data gathering in order to ensure the program will meet the needs of the local population. For example, in our focus groups, we learned that Wednesdays were not an ideal day to have programs in the housing community because seniors ride free on Wednesdays on the city public transit. Therefore, many residents try to use Wednesdays for shopping, medical appointments, and other errands around town. To accommodate this, we held the program on Thursday afternoons instead. We suggest other researchers collect information about availability, location convenience, environmental barriers or constraints to participation, and educational needs and desires of the population. We also recommend tying the project to a university course, if possible, so that student learning outcomes can be reinforced in the classroom regularly. This course would ideally include a simulation component of the student training before the program begins, an essential aspect of IPE so that students can practice their roles interacting with each other as program facilitators (Wen et al., 2019).

Service-learning and IPE are high-impact teaching strategies that have shown positive impacts and learning outcomes in gerontology and geriatric education (De Los Santos et al., 2014; Matthews et al., 2012). However, the specifics about how to integrate service-learning and IPE into a single program or gerontology curriculum is less well-documented in the literature. This 10-week CWB program, which began with a needs assessment and ended with a program evaluation, has demonstrated favorable outcomes for students, older adults, and faculty. Not only does a service-learning project allow students to engage meaningfully 
with the community, but they can also gain valuable first-had experiences (and comfort) working with their future patient population. Three students indicated that this project has made them consider a future career working with older adults in healthcare. Additionally, older adults reported increased social interactions and perceived sense of well-being. Other service-learning IPE programs should involve both students and older adult participants in the program planning and evaluation processes.

\section{Disclosure statement}

The authors declare no conflict of interest.

\section{Funding}

This work was supported by the UAA Faculty Leadership in Expanding Undergraduate Research (FLEUR) Health Award from the Office of Undergraduate Research and Scholarship, and by the UAA Center for Community-Engagement \& Learning.

\section{ORCID}

Britteny M. Howell (D) http://orcid.org/0000-0002-9724-5367

Leslie C. Redmond (D) http://orcid.org/0000-0001-7924-630X

\section{References}

Bringle, R. G., Games, R., Foos, C. L., Osgood, R., \& Osborne, R. (2000). Faculty fellows program: Enhancing integrated professional development through community service. American Behavioral Scientist, 43(5), 882-894. doi:10.1177/00027640021955531

Bringle, R. G., \& Hatcher, J. A. (1995). A service-learning curriculum for faculty. Michigan Journal of Community Service Learning, 2(1), 112-122.

Brown, K. M., \& Bright, L. M. (2017). Teaching caring and competence: Student transformation during an older adult focused service-learning course. Nurse Education in Practice, 27, 29-35. doi:10.1016/j.nepr.2017.08.013

Cohen, H. L., Hatchett, B., \& Eastridge, D. (2006). Intergenerational service-learning. Journal of Gerontological Social Work, 48(1-2), 161-178. doi:10.1300/J083v48n01_11

Curran, V. R., Mugford, J. G., Law, R. M., \& MacDonald, S. (2005). Influence of an interprofessional HIV/AIDS education program on role perception, attitudes and teamwork skills of undergraduate health sciences students. Education for Health, 18(1), 32-44. doi:10.1080/ 13576280500042606

Dacey, M., Murphy, J. I., Anderson, D. C., \& McCloskey, W. W. (2010). An interprofessional service-learning course: Uniting students across educational levels and promoting patient-centered care. Journal of Nursing Education, 49(12), 696-699. doi:10.3928/0148483420100831-09

De Los Santos, M., McFarlin, C. D., \& Martin, L. (2014). Interprofessional education and service learning: A model for the future of health professions education. Journal of Interprofessional Care, 28(4), 374-375. doi:10.3109/13561820.2014.889102

Evashwick, C., \& Ory, M. (2005). How to keep a public health and aging program going. Generations, 29(2), 76-81.

Gellis, Z. D., Kim, E., Hadley, D., Packel, L., Poon, C., Forciea, M. A., ... Johnson, J. (2019). Evaluation of interprofessional health care team communication simulation in geriatric palliative care. Gerontology \& Geriatrics Education, 40(1), 30-42. doi:10.1080/02701960.2018.1505617 
Goldberg, L. R., Koontz, J. S., Rogers, N., \& Brickell, J. (2012). Considering accreditation in gerontology: The importance of interprofessional collaborative competencies to ensure quality health care for older adults. Gerontology \& Geriatrics Education, 33(1), 95-110. doi:10.1080/ 02701960.2012 .639101

Gorelik, Y., Damron-Rodriguez, J., Funderburk, B., \& Solomon, D. H. (2000). Undergraduate interest in aging: Is it affected by contact with older adults? Educational Gerontology, 26(7), 623-638. doi:10.1080/03601270050200626

Gould, P. R., Lee, Y., Berkowitz, S., \& Bronstein, L. (2015). Impact of a collaborative interprofessional learning experience upon medical and social work students in geriatric health care. Journal of Interprofessional Care, 29(4), 372-373. doi:10.3109/13561820.2014.962128

Gutheil, I. A., Chernesky, R. H., \& Sherratt, M. L. (2006). Influencing student attitudes toward older adults: Results of a service-learning collaboration. Educational Gerontology, 32(9), 771-784. doi:10.1080/03601270600835470

Haron, Y., Levy, S., Albagli, M., Rotstein, R., \& Riba, S. (2013). Why do nursing students not want to work in geriatric care? A national questionnaire survey. International Journal of Nursing Studies, 50 (11), 1558-1565. doi:10.1016/j.ijnurstu.2013.03.012

Interprofessional Education Collaborative. (2016). Core competencies for interprofessional collaborative practice: 2016 update. Washington, DC: Interprofessional Education Collaborative.

Lally, K. M., Ducharme, C. M., Roach, R. L., Towey, C., Filinson, R., \& Tuya Fulton, A. (2019). Interprofessional training: Geriatrics and palliative care principles for primary care teams in an ACO. Gerontology \& Geriatrics Education, 40(1), 121-131. doi:10.1080/ 02701960.2018 .1459595

Lee, M. L., Hayes, P. A., McConnell, P., \& Henry, R. M. (2013). Students delivering health care to a vulnerable Appalachian population through interprofessional service-learning. Gerontology \& Geriatrics Education, 34(1), 43-59. doi:10.1080/02701960.2013.737388

Matthews, R. L., Parker, B., \& Drake, S. (2012). Healthy ager: An interprofessional, service-learning, town-and-gown partnership. Nursing Education Perspectives, 33(3), 162-165. doi:10.5480/15365026-33.3.162

Mduluza, T., Midzi, N., Duruza, D., \& Ndebele, P. (2013). Study participants incentives, compensation and reimbursement in resource-constrained settings. BMC Medical Ethics, 14(Suppl 1), S4. doi:10.1186/1472-6939-14-S1-S4

Meiboom, A. A., de Vries, H., Hertogh, C. M. P. M., \& Scheele, F. (2015). Why medical students do not choose a career in geriatrics: A systematic review. BMC Medical Education, 15(1), 101. doi:10.1186/s12909-015-0384-4

Meiboom, A. A., De Vries, H., Hertogh, C. M. P. M., \& Scheele, F. (2015). Why medical students do not choose a career in geriatrics: A systematic review Career choice, professional education and development. BMC Medical Education, 15(1), 101. doi:10.1186/s12909-015-0384-4

Morano, C., \& Damiani, G. (2019). Interprofessional education at the meso level: Taking the next step in IPE. Gerontology \& Geriatrics Education, 40(1), 43-54. doi:10.1080/02701960.2018.1515739

Ní Chróinín, D., Cronin, E., Cullen, W., O’Shea, D., Steele, M., Bury, G., \& Kyne, L. (2013). Would you be a geriatrician? Student career preferences and attitudes to a career in geriatric medicine. Age and Ageing, 42(5), 654-657. doi:10.1093/ageing/aft093

Richardson, J. A., Cooper, B., Swanson, L., \& Ward, M. (1996). Interprofessional education in gerontology: A problem-based model. Gerontology \& Geriatrics Education, 16(2), 37-51. doi:10.1300/J021v16n02_05

Schapmire, T. J., Head, B. A., Nash, W. A., Yankeelov, P. A., Furman, C. D., Wright, R. B., .. Jones, C. (2018). Overcoming barriers to interprofessional education in gerontology: The interprofessional curriculum for the care of older adults. Advances in Medical Education and Practice, 9, 109. doi:10.2147/AMEP.S149863

Steinke, P., \& Fitch, P. (2014). Using goal-based learning to understand why service-learning improves cognitive outcomes. Currents in Teaching \& Learning, 7(1), 50-63.

Tam, M. (2014). Intergenerational service learning between the old and young: What, why and how. Educational Gerontology, 40(6), 401-413. doi:10.1080/03601277.2013.822201 
U.S. Census Bureau. (2018). Annual estimates of the resident population: April 1, 2010 to July 1, 2018. Retrieved from Https://Factfinder.Census.Gov/Faces/Tableservices/Jsf/Pages/Productview.Xhtml? Src $=$ bkmk

Vandsberger, E., \& Wakefield, M. (2006). Service learning with rural older adults. Journal of Intergenerational Relationships, 3(4), 83-97. doi:10.1300/J194v03n04_06

Wallerstein, N. B., \& Duran, B. (2006). Using community-based participatory research to address Health disparities. Health Promotion Practice, 7(3), 312-323. doi:10.1177/1524839906289376

Wen, A., Wong, L., Ma, C., Arndt, R., Katz, A. R., Richardson, K., ... Masaki, K. (2019). An interprofessional team simulation exercise about a complex geriatric patient. Gerontology \& Geriatrics Education, 40(1), 16-29. doi:10.1080/02701960.2018.1554568

WHO. (2010). Framework for action on interprofessional education and collaborative practice. Geneva, Switzerland: World Health Organization Press.

Zucchero, R. (2010). Share your experience and I'll lend you my ear: Older adult outcomes of an intergenerational service-learning experience. Gerontology \& Geriatrics Education, 31(4), 383-402. doi:10.1080/02701960.2010.528275

\section{Appendix A. The focus group guide}

This is a list of general topics to get the focus groups started. We are interested in learning what aspects of health the residents care about. We want to know what information about diet/nutrition and exercise/physical activity they need, want, are missing, etc. We also want to capture what they think works and what does not work about having health programs here at XXX community. You may reword these questions as you see fit, but try to use positive, person-first language that helps people to realize that there are always things we can do to help increase our health.

- Introduce self and student research assistants

- Introduce purpose of the focus group and hopes for creation of the health program

- Read the consent form and collect signed forms from each participant

- Participants who decline to sign the form will not be able to participate in the focus group

(1) Have you participated in any events or programs here at XXX community?

(a) If so, which ones?

(b) If so, what did you think about them? What worked or what didn't?

(c) If not, why not?

(2) What are your thoughts on diet and nutrition (i.e. what comes to mind)?

(3) What do you want to learn about nutrition?

(a) If no responses, ask if they are interested in learning how to shop on a budget? Cook on a budget? How to read a food label?

(4) What do you struggle with (what challenges you) about eating healthy?

(5) What comes to mind when I say "physical activity?"

(6) Are physical activity and exercise the same thing? If not, why not?

(7) How much activity to you get, when, and why or why not?

(8) What activities do you enjoy? Not enjoy? What physical limitations do you have?

(9) What challenges do you face in getting daily physical activity?

(10) What are you interested in learning about physical activity?

(a) For example, how to modify or adaptive activities, safety, etc?

(11) What other aspects about health and wellness are you interested in learning about?

(a) Prompts may include stress reduction, reducing boredom, increasing flexibility, reducing the risk of falls, etc.

(12) What days/times would you like to attend a health program here at the XXX community?

(13) Is there anything else we should know as we create a health promotion program for residents at the XXX community?

Thank you very much for your time! 


\section{Appendix B. The participant satisfaction survey}

Thank you for attending the Community Wellness Breaks Program from the University of Alaska Anchorage! Your feedback is extremely important. By completing this form, you will help us get to know our audience better and to improve future programs.

\section{Demographics}

1. What is your sex/gender identification?
$\square$ Male
$\square$ Female
$\square$ Other

2. What is your ethnicity?
$\square$ White
$\square$ Black or African American
$\square$ Native Hawaiian or Pacific Islander
$\square$ Hispanic/Latino
$\square$ Biracial/multiracial
$\square$ Asian
$\square$ Unknown
$\square$ Other

3. What is your age?
$\square$ 30-39 years
$\square$ 40-49 years
$\square$ 50-59 years
$\square$ 60-69 years
$\square$ 70-79 years
$\square$ 80-89 years
$\square 90+$ years

Please indicate your agreement with the following statements by filling in the appropriate circle.

\begin{tabular}{|c|c|c|c|c|c|}
\hline & $\begin{array}{l}\text { Strongly } \\
\text { agree }\end{array}$ & $\begin{array}{c}\text { Mostly } \\
\text { agree }\end{array}$ & Neutral & $\begin{array}{c}\text { Mostly } \\
\text { disagree }\end{array}$ & $\begin{array}{l}\text { Strongly } \\
\text { disagree }\end{array}$ \\
\hline Satisfaction & $\bigcirc$ & $\bigcirc$ & $\bigcirc$ & O & O \\
\hline $\begin{array}{l}\text { 1. Overall, I was satisfied with the students' teaching } \\
\text { performance. }\end{array}$ & $\bigcirc$ & $\bigcirc$ & $\bigcirc$ & $\bigcirc$ & $\bigcirc$ \\
\hline 2. The physical environment was conducive to learning. & O & O & ○ & O & ○ \\
\hline $\begin{array}{l}\text { 3. Overall, I was satisfied with the quality of this } \\
\text { educational program. }\end{array}$ & O & $\bigcirc$ & $\bigcirc$ & $\mathrm{O}$ & $\bigcirc$ \\
\hline $\begin{array}{l}\text { 4. I acquired new knowledge and skills from this } \\
\text { program. }\end{array}$ & $\mathrm{O}$ & O & O & $\mathrm{O}$ & $\mathrm{O}$ \\
\hline Learning & $\begin{array}{r}\text { Strongly } \\
\text { agree }\end{array}$ & $\begin{array}{c}\text { Mostly } \\
\text { agree }\end{array}$ & Neutral & $\begin{array}{l}\text { Mostly } \\
\text { disagree }\end{array}$ & $\begin{array}{l}\text { Strongly } \\
\text { disagree }\end{array}$ \\
\hline $\begin{array}{l}\text { 5. I will be able to apply what I learned in this program to } \\
\text { my daily life. }\end{array}$ & 0 & ○̊ & O & $\mathrm{O}$ & 0 \\
\hline Application & $\bigcirc$ & $\bigcirc$ & $\bigcirc$ & $\bigcirc$ & $\bigcirc$ \\
\hline $\begin{array}{l}\text { 6. This program is important for improving health and } \\
\text { quality of life outcomes. }\end{array}$ & $\bigcirc$ & $\bigcirc$ & $\bigcirc$ & $\bigcirc$ & $\bigcirc$ \\
\hline Impact & O & O & O & O & O \\
\hline $\begin{array}{l}\text { 7. This program can help increase social interactions in } \\
\text { my living community. }\end{array}$ & $\bigcirc$ & $\bigcirc$ & $\bigcirc$ & O & O \\
\hline $\begin{array}{l}\text { 8. This program was a worthwhile investment for my } \\
\text { living community. }\end{array}$ & O & O & O & $\bigcirc$ & ○ \\
\hline $\begin{array}{l}\text { 9. This program was a worthwhile investment of my } \\
\text { time. }\end{array}$ & $\mathrm{O}$ & $\mathrm{O}$ & O & O & O \\
\hline
\end{tabular}




\section{Feedback}

What do you think was the most valuable information for you during this program?

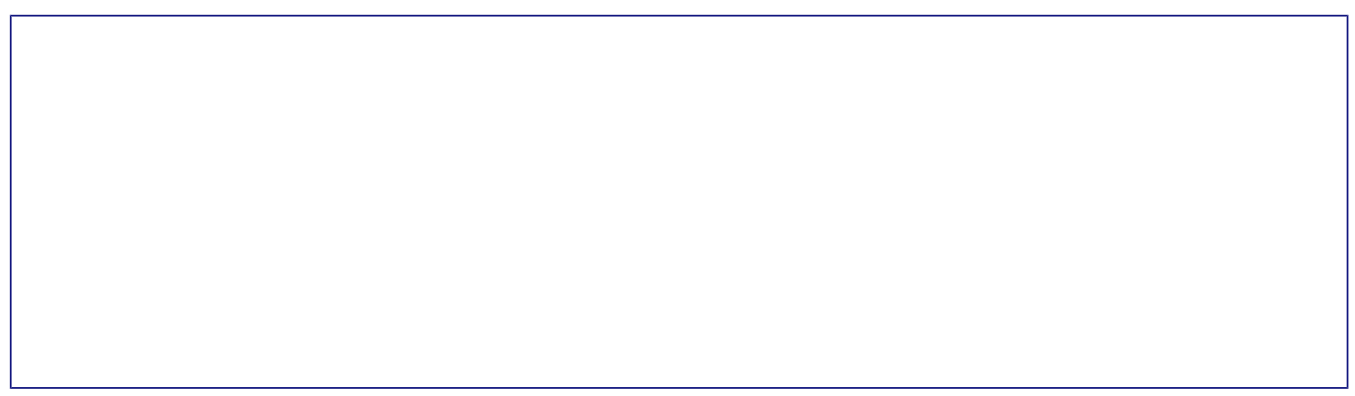

What do you think was the least valuable information for you during this program?

What could we do better in future programs at UAA? 